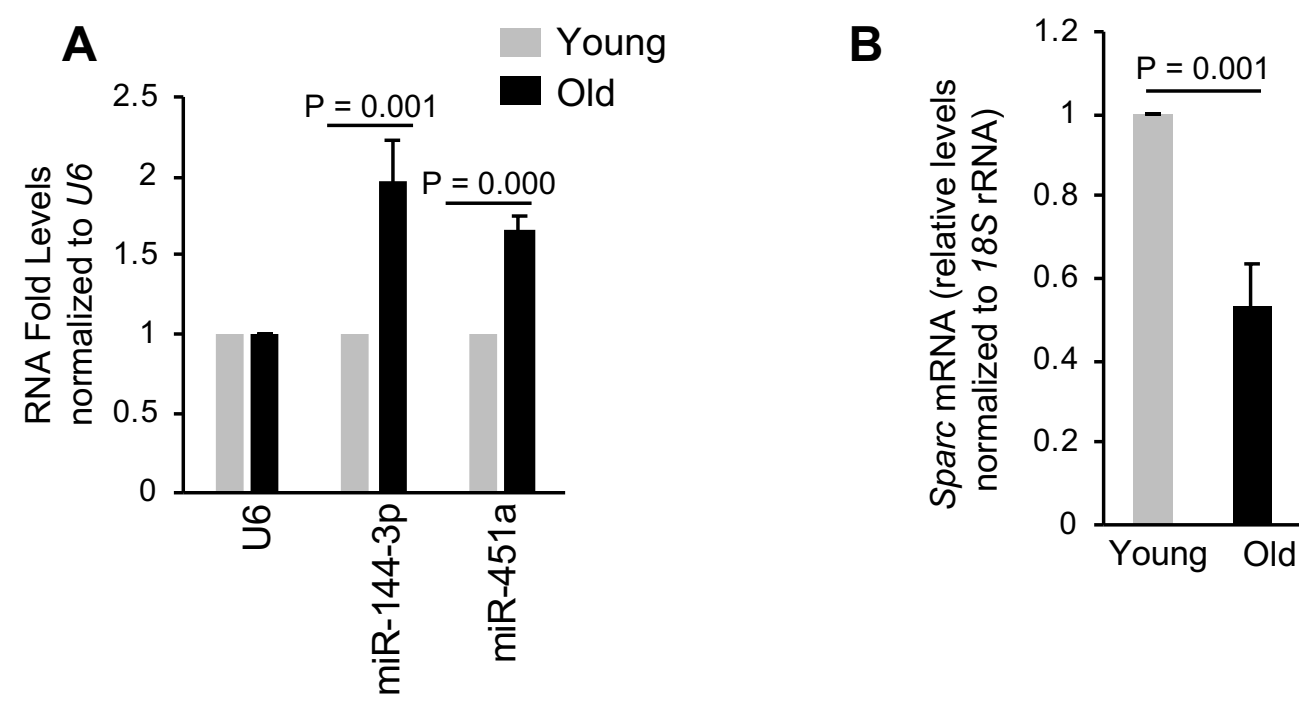

C

\title{
Skeletal muscle
}

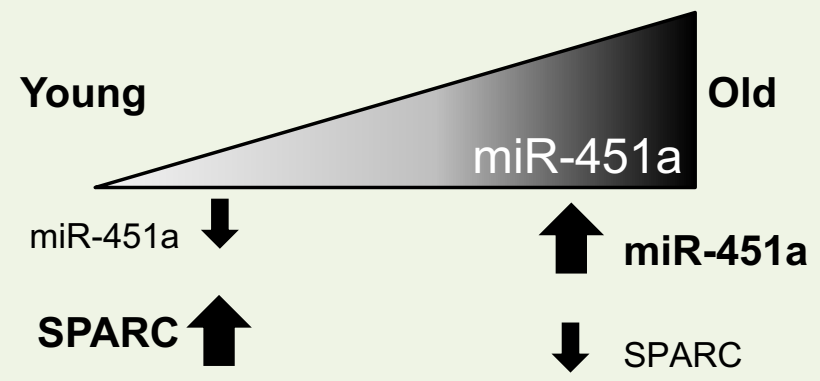

Muscle Regeneration $\downarrow$ 